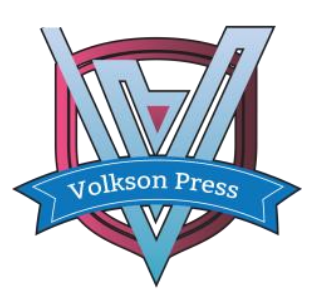

Contents List available at VOLKSON PRESS

Economics \& Management Innovations(EMI)

DOI : http://doi.org/10.26480/icemi.01.2017.381.383

\title{
Analysis of the Competitive Strategy of Supply Chain Finance-A Case Study of Chinese Supply Chain Financial Enterprises
}

\author{
Sang-Bing Tsai ${ }^{1,2}$ \\ ${ }^{1}$ Law School, Nankai University, Tianjin 300071, China \\ 2Zhongshan Institute, University of Electronic Science and Technology of China, Guangdong 528402, China \\ E-mail:sangbing@hotmail.com
}

This is an open access article distributed under the Creative Commons Attribution License, which permits unrestricted use, distribution, and reproduction in any medium, provided the original work is properly cited.

\section{ARTICLE DETAILS}

\section{Article History:}

Received 02 october 2017

Accepted 06 october 2017

Available online 11 october 2017

Keywords:

Supply Chain Finance, FinTech,

Finance Law, Competitive

Strategy, Internet finance.

\section{ABSTRACT}

Supply chain finance (SCF) is a professional field of the credit business of commercial banks, as well as a financing channel for enterprises, especially small and medium enterprises (SMEs). SCF originated from traditional banks; however, under the impact of the Internet, the financial threshold is lowered. Internet financing provides more choices to the market, and is a prominent challenge for the practitioners of SCF to distinguish themselves in SCF market competition, raise service quality, and strengthen their competitive strategy. The Importance-Performance Analysis (IPA) model is often used to measure performance and analyze competitive strategy. This study adopts IPA to analyze and inspect the SCF service performance of the subject, and learns its advantages and disadvantages for use as a reference for improvement.

\section{Introduction}

The supply chain is a functional network structure that controls information flow, logistics, and capital flow, which starts from the procurement of raw materials, produces intermediate and final products, sends the products to consumers through sales networks, and integrates suppliers, manufacturers, distributors, retailers, and end users. It is more than a link to connect the information flow, logistics, and capital flow between suppliers and users, it is also a value-added chain; due to processing, packaging, and transportation, the value of materials is increased, resulting in benefits to the relevant enterprises ${ }^{[1]}$.

SCF is a professional field of the credit business of commercial banks, as well as a financing channel for enterprises, especially SMEs. Through SCF, banks offer financing and other settlement and financial services to customers (core enterprises), provide loans and instant income to suppliers, or advance and inventory financing services to distributors. Simply put, SCF is a financing model through which banks connect core enterprises and upstream and downstream enterprises to provide flexible financial products and services ${ }^{[2]}$. While the above definition is extremely close to that of the traditional factors of business and mortgage business (real estate and property in goods pledge/pledge credit granting), there is an obvious difference. Factoring and mortgage businesses are simple trade financing products, while SCF is a systematic financing arrangement agreed between core enterprises and banks for all the member enterprises in the supply chain.

SCF is still at the stage of initial development in China; however, due to the continuous development of receivables, commercial bills, and the finance and leasing market, SCF is rapidly developing in China ${ }^{[3]}$. At present, Chinese SCF is concentrated in the fields of computer communication power equipment, automobiles, chemical industry, coal, steel, medicine, nonferrous metals, agricultural and sideline products, and furniture manufacturing, the commercial banks, core enterprises, logistics enterprises, and e-commerce platforms participate in SCF competition. China's SCF market size is said to exceed USD10 trillion. With the development of Internet+, China's SCF market grows year by year, and was expected to reach USD11.97 trillion by 2015 and USD14.98 trillion by $2020^{[3-4]}$

This study regards Chinese SCF enterprises as its subjects, and intends to identify the quality indicators influencing customer satisfaction with SCF enterprises, in order to serve as a reference for the future development of SCF and decision-making for competitive strategies.

\section{Literature Review - Characteristics of SCF}

Generally, the supply chain of a specific product starts from the procurement of raw materials, produces intermediate and final products, sends the products to consumers through sales networks, and integrates suppliers, manufacturers, distributors, retailers, and end users. In this supply chain, core enterprises with stronger competitiveness and larger scale have advantageous status, due to their strict requirements for upstream and downstream supporting enterprises in terms of delivery, price, and terms, resulting in huge pressure to the latter. Most upstream and downstream supporting enterprises are SMEs, which have difficulty in financing, thus, they tend to suffer from a tight capital chain and an unbalanced supply chain ${ }^{[5]}$.

The biggest characteristic of SCF is to find one large core enterprise, and taking this enterprise as the starting point, offer financial support to its supply chain ${ }^{[6]}$. On the one hand, funds are effectively injected into the upstream and downstream supporting SMEs in relative disadvantageous status, in order to solve their difficulties in financing and dealing with an unbalanced supply chain. On the other hand, bank credit is integrated with the purchase and sales of upstream and downstream enterprises to enhance their commercial credit, promote long-term and strategic cooperation between SMEs and core enterprises, and improve the competitiveness of the supply chain. In the "SCF" financing model provided the enterprises in the supply chain have support from banks, and the "umbilical cord blood" of funds are injected to them, the entire supply chain benefits from the funds. Moreover, with the support of bank credit, SMEs can gain more business opportunities.

SCF originated from traditional banks; however, under the impact of the Internet, the financial threshold is lowered. Internet financing provides more choices to the market. In the SCF model, the relevant enterprises in the supply chain can share the funding risks with core enterprises ${ }^{[7]}$. With the credit support of the core enterprises, the upstream and downstream enterprises can obtain credit limits with lower cost.

\section{Research Method}

The basic framework of Importance-Performance Analysis (IPA) was first 
proposed by Martilla and James, who also conducted relevant practical applications [8]. The averages of importance and performance of an attribute are marked on a two-dimensional figure, where the vertical axis is the degree of importance and the horizontal axis is the degree of performance, as shown in Figure $1{ }^{[9-13]}$.

The four quadrants of IPA have their respective definitions [14-19]:

Keep up the good work: It means that customers attach great importance to this area and feel satisfied with the performance of an enterprise.

Concentrate here: It means that customers attach great importance to this area, but are not satisfied with the performance of an enterprise.

Low priority: It indicates that customers are not satisfied with the importance or performance of an enterprise.

Possible overkill: In implies that customers do not stress the attributes in this area, but they are satisfied with the performance of an enterprise.

With the classification of different areas, managers can use limited resources in the most efficient manner and clarify priorities for improvement, in order to improve satisfaction [20-24]. With IPA, attributes can easily be analyzed, thus, it has been widely applied by many scholars to other fields, and used as a tool to analyze the priority of attributes to meet the needs of customers ${ }^{[25-28]}$.

\begin{tabular}{c|c} 
Concentrate here & \multicolumn{2}{c}{ Keep up the good work } \\
\hline Low priority & Possible overkill
\end{tabular}

Figure 1. Importance and performance analysis

\section{Research Results and Discussion}

Company A is a Top 3 SCF enterprise in China. This study considers Company A as its subject and evaluates its SCF performance as reference for improvement. This questionnaire, applied from April 1 to 20, 2017, adopts a Likert seven-point scale with 10 questions to investigate 50 enterprise customers of Company A. There are 50 official questionnaire copies distributed, and 44 valid questionnaires are collected, for a recovery rate of $88 \%$.

This study regards the averages of importance (5.78) and performance (5.82) as the standard coordinates to determine the good or poor performance of each indicator. See Table 1 for details.

According to the results of IPA analysis, the three indicators of: (4) costs for contacts with companies, (5) degree of rationality of interest rate, and (6) non-monetary costs for contacts with companies, such as the time and energy of Company A belong to "Keep up the good work". These are the advantages of Company A, which shall be retained to maintain its performance and enhance customer satisfaction.

The two indicators of: (1) assistance in solving difficulties for customers and (2) the degree of importance attached to the interests of customers of Company A belong to "Concentrate here". Company A must concentrate its resources to raise the performances of these two indicators to turn disadvantages to advantages.

In addition, the importance of the two indicators of: (3) degree of professionalism of employees and (7) convenience of procedures is low, but with high performance, thus, they belong to "Possible overkill". Company A has good performance, but fails to bring about more performances. Hence, its resources shall be shifted to other attributes.
Lastly, the two indicators of: (8) completeness of financial services and (9) modernism and technicalization of corporate equipment belong to "Low priority". Company A has poor performance and low importance. Thus, the least importance shall be given to these aspects. When the company has redundant resources, it can improve these aspects.

See Table 1 for details.

Table 1. Importance and performance analysis

\begin{tabular}{|c|c|c|c|c|}
\hline Order & Content & Importance & Performance & $\begin{array}{l}\text { Competitive } \\
\text { Strategy }\end{array}$ \\
\hline 1 & $\begin{array}{l}\text { Assistance in } \\
\text { solving difficulties } \\
\text { for customers }\end{array}$ & 5.9 & 5.6 & $\begin{array}{c}\text { Concentrate } \\
\text { here }\end{array}$ \\
\hline 2 & $\begin{array}{l}\text { Degree } \\
\text { importance } \\
\text { attached to the } \\
\text { interests } \\
\text { customers }\end{array}$ & 5.9 & 5.4 & $\begin{array}{c}\text { Concentrate } \\
\text { here }\end{array}$ \\
\hline 3 & $\begin{array}{l}\text { Degree of } \\
\text { professionalism of } \\
\text { employees }\end{array}$ & 5.4 & 5.9 & $\begin{array}{l}\text { Possible } \\
\text { overkill }\end{array}$ \\
\hline 4 & $\begin{array}{l}\text { Cost for contacts } \\
\text { with companies }\end{array}$ & 6.2 & 6.3 & $\begin{array}{l}\text { Keep up the } \\
\text { good work }\end{array}$ \\
\hline 5 & $\begin{array}{ll}\text { Degree } & \text { of } \\
\text { rationality } & \text { of } \\
\text { interest rate } & \end{array}$ & 6.0 & 5.9 & $\begin{array}{l}\text { Keep up the } \\
\text { good work }\end{array}$ \\
\hline 6 & $\begin{array}{l}\text { Non-monetary } \\
\text { cost for contacts } \\
\text { with companies, } \\
\text { such as time and } \\
\text { energy }\end{array}$ & 5.9 & 6.1 & $\begin{array}{l}\text { Keep up the } \\
\text { good work }\end{array}$ \\
\hline 7 & $\begin{array}{l}\text { Convenience of } \\
\text { procedures }\end{array}$ & 5.6 & 5.9 & $\begin{array}{l}\text { Possible } \\
\text { overkill }\end{array}$ \\
\hline 8 & $\begin{array}{l}\text { Completeness of } \\
\text { financial services }\end{array}$ & 5.5 & 5.6 & Low priority \\
\hline 9 & $\begin{array}{l}\text { Modernism and } \\
\text { technicalization of } \\
\text { corporate } \\
\text { equipment }\end{array}$ & 5.6 & 5.7 & Low priority \\
\hline Average & & 5.78 & 5.82 & \\
\hline
\end{tabular}

\section{Conclusion}

This study regarded Chinese SCF enterprises as its subjects, and hoped to identify the quality indicators influencing customer satisfaction with SCF enterprises, which can serve as a reference for the future development of SCF and decision-making for competitive strategies.

This study shows that, the three indicators of: (4) cost for contacts with companies, (5) degree of rationality of interest rate, and (6) non-monetary cost for contacts with companies, such as the time and energy of Company A, belong to "Keep up the good work". These are the advantages of Company A, which shall be retained to maintain its performance and enhance customer satisfaction. The two indicators of: (1) assistance in solving difficulties for customers and (2) the degree of importance attached to the interests of the customers of Company A, belong to "Concentrate here". Company A must concentrate its resources to raise the performances of the two indicators to turn disadvantages to advantages.

\section{References}

[1] Report by McKinsey: Blockchain-Disrupting the Rules of the Banking Industry, 2016-05.

[2] Bitcoin Chain B: Standard Chartered Completed 10-Second CrossBorder Payment Using

Blockchain, http://chainb.com/?P=Cont\&id=2327, 2016-09-30/ 2016$10-23$

[3] Shared Finance: Giant Leap by National Australia Bank: Successful Payment Transfer by NAB

Using Blockchain, http://www.gongxiangcj.com/show-22-2130-

1.html, 2016-09-22/

2016-10-23.

[4] Report by McKinsey: Blockchain—Disrupting the Rules of the Banking Industry, 2016-05. 
[5] Weiyangx: Barclays Bank completes its first blockchain-based tradefinance

transaction, http://www.weiyangx.com/205645.html, 2016-09-09/ 2016-10-23.

[6] Central Depository \& Clearing Co., Ltd. 2015 Report on

Developments in Asset Securitization.

[7] Report by China International Capital Corporation, Changing the Infrastructure of the Financial Sector.

[8] Martilla, J. A. \& James, J. C. 1977. Importance-Performance Analysis. Journal

Marketing, 41 (1), 77-79.

[9] Tsai, S.B., Wei, Y.M., Chen, K.Y., Xu, T., et al. 2016. Evaluating Green Suppliers

from Green Environmental Perspective. Environment and Planning BPlanning \& Design, 2016, 43(5), 941-959.

[10] Tsai, S.B. 2016. Using Grey Models for Forecasting China's Growth Trends in Renewable Energy Consumption. Clean Technologies and Environmental Policy, 2016, 18, 563-571.

[11] Guo, J.J. and Tsai, S.B. 2015. Discussing and Evaluating Green Supply Chain Suppliers: A Case Study of the Printed Circuit Board Industry in China. South African Journal of Industrial Engineering, 2015, 26(2), 56-67.

[12] Tsai, S.B., Huang, C.Y., Wang, C.K., Chen, Q., et al. 2016. Using a Mixed Model to Evaluate Job Satisfaction in High-Tech Industries. Plos One, 2016, 11(5): e0154071. doi:10.1371/journal.pone.0154071

[13] Lee, Y.C., Chu, W.H., Chen, Q., Tsai, S.B., et al. 2016. Integrating DEMATEL Model and Failure Mode and Effects Analysis to Determine the Priority in Solving Production Problems. Advances in Mechanical Engineering, 2016, 8(4), 1-12.

[14] Tsai, S.B., Xue, Y., Zhang, J., Chen, Q., et al. 2016. Models for Forecasting Growth Trends in Renewable Energy. Renewable \& Sustainable Energy Reviews, 2016, DOI: 10.1016/j.rser.2016.06.001.

[15] Qu, Q., Chen, K.Y., Wei, Y.M., et al. 2015. Using Hybrid Model to Evaluate Performance of Innovation and Technology Professionals in Marine Logistics Industry Mathematical Problems in Engineering, 2015, Article ID 361275, 8 pages, http://dx.doi.org/10.1155/2015/361275.

[16] Zhou, J. Wang, Q., Tsai, S.B., et al. 2016. How to Evaluate the Job Satisfaction of Development Personnel. IEEE Transactions On Systems Man Cybernetics-Systems, 2016, 10.1109/TSMC.2016.2519860.
[17] Su, J. M., Lee, S. C., Tsai, S. B. \& Lu, T. L. 2016. A comprehensive survey of the relationship between self-efficacy and performance for the governmental auditors. SpringerPlus, 2016, 5:508. DOI 10.1186/s40064016-2104-x

[18] Tsai, S.B., Lee, Y.C. \& Guo, J.J. 2014. Using modified grey forecasting models to forecast the growth trends of green materials. Proceedings of the Institution of Mechanical Engineers, Part B: Journal of Engineering Manufacture, 2014, 228(6): 931-940.

[19] Chen, H.M., Wu, C.H., Tsai, S.B., Yu, J., et al. 2016. Exploring key factors in online shopping with a hybrid model. SpringerPlus, 2016, 5:2046. DOI 10.1186/s40064-016-3746-4.

[20] Deng, X.Y., Hu, Y., Deng Y. \& Mahadevan, S. 2014. Environmental impact assessment impact assessment based on numbers. Expert Systems with Applications, 2014, 41 (2), 635-643.

[21] Wang, J., Yang, J., Chen Q. \& Tsai, S.B. 2016. Collaborative Production Structure of Knowledge-sharing Behavior in Internet Communities. Mobile Information Systems, Article ID 8269474, 9 pages, http://dx.doi.org/10.1155/2016/8269474.

[22] Wang, J., Yang, J., Chen Q. \& Tsai, S.B. 2016. Creating the Sustainable Conditions for Knowledge Information Sharing in Virtual Community. SpringerPlus, 5:1019, DOI 10.1186/s40064-016-2702-7.

[23] Lee, Y.C., Wang, Y.C., Chien, C.H., Wu, C.H., et al. 2016. Applying Revised Gap Analysis Model in Measuring Hotel Service Quality, SpringerPlus, 5:1191, DOI 10.1186/s40064-016-2823-z.

[24] Lee, Y.C., Wang, Y.C., Lu, S.C., Hsieh, Y.F., et al. 2016. An Empirical Research on Customer Satisfaction Study: A Consideration of Different Levels of Performance. SpringerPlus, 5:1577, DOI 10.1186/s40064-0163208-z.

[25] Chin, T., Tsai, S.B., Fang, K., Zhu, W., et al. 2016. EO-Performance relationships in Reverse Internationalization by Chinese Global Startup OEMs: Social Networks and Strategic Flexibility. PLoS ONE, 11(9) e0162175, doi:10.1371/journal.pone.0162175.

[26] Lee, S.C., Su, J.M., Tsai, S.B., Lu, T.L., et al. 2016. A comprehensive survey of government auditors' self-efficacy and professional Development for improving audit quality. SpringerPlus, 5:1263, DOI 10.1186/s40064-016-2903-0.

[27] Chen, H.M., Wu, C.H., Tsai, S.B., Yu, J., et al. 2016. Exploring key factors in online shopping with a hybrid model. SpringerPlus, 5:2046, DOI $10.1186 / s 40064-016-3746-4$. 